Francisco Javier

\section{RODRÍGUEZ BARRANCO}

\section{PELIS DE HOY (2011 - 2015)}

Málaga: Ediciones Azimut. 2017. pp. 352.

La célebre aseveración de Jorge Luis Borges de que se enorgullecía mucho más de los libros que había leído que de los que había escrito nos abre una apasionante vía de pensamiento y no debe en absoluto considerarse una salida ingeniosa ni una boutade. Si valoramos al artista por su obra - en cualesquiera disciplinas - hemos de admirar también al sabio admirador, al que sabe apreciarla con criterio científico y buen gusto estético, precisamente porque ésta es una especie cultural que escasea en grado sumo. No sería de esta manera si los espectadores del filme o la obra teatral, si los oyentes de la música y los lectores de los textos poseyeran en un grado aceptable esa capacidad de ponderación y juicio. Pero lamentablemente no es así. Las películas más vistas y apreciadas en cada año han sido las iniciales y las secuelas de James Bond, Indiana Jones y Harry Potter, no los filmes de Kubrick, Wilder o Kurosawa. Hay en la actualidad un plebeyismo entre los "consumidores de cultura" que los lleva a preferir y a encumbrar obras artísticas muy mediocres. Y como muchas veces lo hacen dirigidos y alentados por los especialistas, cobra más valor el crítico culto, analítico y constructivo que sabe interpretar el arte de su época y fijar los parámetros para su juicio posterior. Francisco Javier Rodríguez Barranco es un crítico cinematográfico tremendamente sagaz que dignifica el oficio de tal y compensa muchas veces los desaguisados de otros menos comprometidos con la verdad o simplemente poco capacitados para la labor.

El presente libro es una selección del trabajo de este experto, en el que ha querido sintetizar el sentir del siglo que llevamos a través de la interpretación que el cine hace de él. No ha rehuido el problema con la excusa de que no se puede juzgar lo contemporáneo por falta de perspectiva. Esto es una falacia y hasta una cobardía. Precisamos de un entendimiento claro del mundo en el que vivimos y dárnoslo es una de las funciones de las artes y de los que nos acercan dichas artes. Así, el autor analiza películas recientes, inmediatas, con los ojos de esa misma modernidad.

Nos advierte en su prólogo que se ha tomado confianzas en el título denominando familiarmente "pelis" a las que no son sino "señoras películas", elegidas entre producciones de los cinco continentes y de muy variados subgéneros, por su calidad y sus referencias conceptuales o estéticas, nos dice. Recalca la importancia intrínseca de las cintas que comenta y también su pertinencia, lo adecuado de sus temas y tratamientos en nuestro momento. Nos anticipa que ha hecho uso de una curiosa pero muy válida herramienta hermenéutica: el logaritmo filosófico, lo que viene a significar que analiza las películas con un criterio científico y riguroso, y a la vez humanístico y profundo, no limitándose a la superficial deconstrucción de aspectos de interpretación o montaje a la que otros críticos nos tienen acostumbrados.

¿Cuál es el resultado de tal acercamiento al cine? Pues que lo que este libro incluye no interesará únicamente a los aficionados al séptimo arte, sino también a cualquier persona inteligente y sensible que se preocupe por una serie de temas vitales de nuestros días a los que las películas seleccionadas sirven de base de debate. Rodríguez Barranco analiza sus filmes con unos planteamientos que ya de por sí atraen e intrigan y que sirven de encabezados a sus capítulos: conflicto de realidades, cotidianidad trascendental, coexistencia de contrarios, pasiones analógicas, espejos rebeldes... Sus reflexiones son de gran valor y enteramente personales e intransferibles, al no haber podido contar con una bibliografía que pudiera servirle de guía ni autoridades en las que apoyarse para evitarse las 
responsabilidades de una opinión muy personal.

El autor es también novelista y eso se deja entrever por su elegante prosa y gran dominio de la lengua, otro mérito que no tendría por qué serlo ni por qué mencionarse si todos los libros estuvieran tan bien escritos como éste. Además, el estilo no es frío y académico, como erróneamente se le suele exigir a los textos críticos. Su variedad, originalidad y cercanía proporcionan una grata lectura.

Lo que en modo alguno podemos permitir es que de una película como Dogville (2003), de Lars von Trier, a pesar de haber obtenido el premio David de Donatello a la Mejor película de la Unión Europea, nadie haya dicho que es una recreación de la Divina Comedia, de Dante. Sin embargo, ¿qué otra cosa puede ser una obra en que la protagonista se llama Grace - por cierto, magnífica Nicole Kidman en su papel de belleza naif-, consta de un prólogo y nueve escenas, de la misma manera que el Infierno de la Comedia consta de un prólogo y nueve Círculos, Grace es escarnecida en cada una de la nueve estancias y el padre les castiga con el fuego de los lanzallamas? Si es que no puede ser otra cosa más que el Infierno, efectivamente. La ciudad de los perros, el sumidero de los pecadores. El fuego del infierno. Y por si eso fuera poco, a Dogville sucedió Manderlay, cuyo cartel es como el negativo del de la película protagonizada por Nicole Kidman ¿Y qué sucede en Manderlay? ¿Qué historia se nos cuenta en esta cinta? La tensión entre esclavitud y libertad ¿Y de qué puede esto ser una parábola? Claro, del Purgatorio, que es la segunda región mística de las incluidas en la descomunal obra del poeta florentino.

Algo así podríamos afirmar de uno de los iconos del frikismo actual: El gran Lebowski. Porque, vamos a ver, ¿a quién nos recuerda la estética de Jeff Bridges en su papel del Lebowski Nota? Obviamente a Carlos Marx, cuyo antagonista, el desencadenante de toda la trama es el Lebowski Capital. De hecho, en el primer encuentro que mantienen ambos, el Capital le dice al Nota: "Tu revolución ha terminado", siendo así que en la elegía que Friedrich Engels dedicó a Marx le consideró como la encarnación del espíritu revolucionario. El desprecio, en las palabras y en las acciones, del Nota al capital también me parece muy elocuente. Por ello, en la primera escena le vemos firmando un talón de 0,69 dólares en un supermercado por un cartón de leche, que ya se ha medio bebido, vestido con albornoz y gayumbos, lo que se nos antoja una burla ingeniosa del sistema. Nada que ver con el prêt-a-pòrter.

Con todo, conviene que nos situemos adecuadamente en lo que los hermanos Coen pretenden, puesto que no se trata de trasladar estrictamente a las pantallas de finales del siglo XX la efervescencia ideológica de la segunda mitad del XIX. No se trata de una adaptación a nuestros días de las vicisitudes filosóficas y vitales de los grandes pensadores decimonónicos. Lo que estos cineastas acometen en este filme, así como en gran parte de su producción, es una fantasía inspirada en grandes obras, corrientes de pensamiento o personajes que han significado algo así como puntos de inflexión en la Historia de la Humanidad. Pongamos un ejemplo que considero suficientemente esclarecedor, pues en determinado momento, en la bolera donde se sucede gran parte del filme, como si de la Acrópolis ateniense se tratara, se suscita una confusión explicita entre John Lennon y Vladimir Ilich Uliánov, alias Lenin, cuando el Nota afirma que si buscas a la persona que se beneficia de algo, entonces descubrirás quién ha causado una situación. Lenin-Lennon: tampoco estuvieron tan lejos ideológicamente.

De manera que, los Coen se inspiran muy libremente en el caldo de cultivo que constituyeron las filosofias positivistas para desarrollar su película y si Marx estuvo acompañado durante toda su andadura socialista por Engels, el Nota lo está por Walter Sobchack, interpretado por John Goodman. Pelo corto y barba larga muestra Engels en las fotografías que se conservan de él, pelo a cepillo y barba corta Walter en el 
filme. Eternos descontentos ambos, partidarios también de la acción directa contra las injusticias cotidianas. Alemanes fueron Marx y Engels, alemanes son los nihilistas de $E l$ gran Lebowski, y alemanes son los sueños eróticos del Nota, que se pueblan de algo tan nibelungo y tan wagneriano como las walkirias.

Demasiadas coincidencias como para ignorar la proyección filosófica de la película que nos ocupa, recreación libre de las ideas que bulleron en la Europa del XIX.

Podemos aún seguir profundizando las referencias culturales que sostienen esta producción, puesto que no podemos ignorar la raíz judía del comunismo. Recordemos simplemente que tanto Marx como Engels eran judíos y que Walter en El gran Lebowski profesa de manera radical esa fe hasta el punto de observar rigurosamente el descanso de los sábados, que tan sólo puede vulnerar en casos de vida o muerte.

El Nota y Walter forman equipo de bolos junto a Donny, constantemente inseguro incluso de las cuestiones más obvias. Pues bien, ¿quién fue el gran compañero de pensamiento de Marx y Engels? Hegel, cuyo bucle dialéctico, tesis más antítesis nos da una síntesis, muy bien puede haber sido parodiado por los Coen en la fragilidad mental de Donny.

Debemos aludir asimismo al crack de la bolera, al superhombre de las competiciones, interpretado por John Turturro, que funciona a caballo entre Zaratustra y el vértigo de situarse más allá del bien y del mal, todo lo cual ha de recordarnos necesariamente a Nietzsche. No en vano se llama Jesus ( $\sin$ tilde: al anglosajón modo) y viene aureolado por una de las más repugnantes perversiones sexuales: la pederastia; lo cual enlaza con el Anticristo, que es el título y el tema de otro de los libros del controvertido filósofo alemán: si es que al anticristo Jesus sólo le falta coserse el nombre boca abajo en la camisa.

Ya hemos mencionado a los nihilistas, que en la película de los Coen aparecen ataviados con estética ninja, y podemos aludir también a otros movimientos ideológicos importantes de finales del siglo XIX o principios del XX, como fueron las mujeres sufragistas que se plasman en la libertad artística y vital de Maude, interpretada por Julianne Moore, e incluso Rodríguez Barranco cree apreciar un guiño a Freud y el psicoanálisis en la estética fálica de Jackie Treehorn, productor de películas pornográficas, interpretado por Ben Gazzara.

Un detalle más añade Barranco al análisis de ese grandioso filme y es que de la misma manera que los griegos tuvieron una Acrópolis para inventar la democracia y los gimnasios para debatirla; los romanos, el Foro; los árabes, los baños, auténticos centros sociales y de poder de la época; $y$, en fin, el té de las cinco en la sociedad victoriana, o los castizos casinos hispánicos en la península; los Coen han cometido la osadía de trasladar el epicentro de su diálogo trascendental a una bolera.

Como una piedra rodante, es la imagen existencial de Bob Dylan. Como una bola rodante, la de los Coen. La vida gira como esa bola y derriba bolos con aspecto antropomorfo.

Por todo ello, considera Rodríguez Barranco que El gran Lebowski es la manera personal y cotidiana que eligieron Ethan y Joel Coen para configurar en nuestros días lo que fue el nacimiento de las sociedades occidentales tal como las entendemos hoy: es tal el cúmulo de sugerencias silenciadas en esta cinta, que el autor de 50 pelis ha considerado necesario saltarse el margen temporal que él mismo se había fijado, de 2011 a 2015, para debatir sobre ellas.

Flaco favor, efectivamente, estamos haciendo al séptimo arte si olvidamos la profundidad de su riqueza ideológica. Y eso es lo que Rodríguez Barranco quiere paliar en este libro, puesto que 50 pelis de hoy, a pesar de su título en apariencia intrascendente, se concibe como un esfuerzo por ampliar los horizontes del cine hasta donde en propiedad le corresponde.

Algo así podríamos decir de las producciones del así llamado Tercer Mundo, tan denodada- 
mente defendido por el profesor Alberto Elena y es que el espectro fílmico mundial quedaría reducido a un patético muñoncito si lo redujéramos a Hollywood, porque más allá de la meca del cine hay vida. Mucha vida, de hecho. Es también Rodríguez Barranco quien en 2015 alumbró su libro 2009, un año de Cine Nostrum, donde ya por su nombre se puede inferir que dirige el foco a las creaciones del Mediterráneo, muy en particular a las películas que cruzan el estrecho de Gibraltar: el cine español en el norte de África y el cine árabe en el sur de España. Pues bien, los cines árabe, africano, del sudeste asiático $\mathrm{y}$, por supuesto, de Latinoamérica, también tiene su espacio en 50 pelis de hoy, donde se concluye, muy en sintonía con la UNESCO, el alto contenido social del cine de esas extensísimas zonas del mundo. Recordemos, por ejemplo, lo que se afirma en la Historia General de África, auspiciada por esa organización supranacional, en relación con el cine africano, pero que puede ser extrapolable al de las regiones más desfavorecidas del planeta: "En general, puede observarse en el cine africano, un interés en sus autores, por enseñar, por educar la conciencia del público. Sus preocupaciones son de orden político (clases sociales, el neocolonialismo, la dependencia), moral (la alienación y los males de la modernidad en oposición con la tradición), didáctico (el papel de las mujeres en el campo, las consecuencias de la droga), personal (los problemas de identidad) o de proselitismo cultural (el arte tradicional como antítesis de la medicina occidental)".

Y no pretendo extenderme más en esta reseña. Dejo 50 pelis de hoy $(2011$ - 2015), de Francisco Javier Rodríguez Barranco, en las manos de los lectores.

Este trabajo sobre el cine que se hace alrededor de las personas, con la perspectiva de la lírica mínima en contraposición a la épica heroica de las batallas de efectos especiales, es - como ya he apuntado- más que un libro de cine; es lo que todo libro debería ser: un pretexto y un acicate para reflexionar sobre el mundo y nuestro lugar en él. Es decir: filosofía de la verdadera. Como a este planteamiento se le añade que un escritor de gran solvencia realiza una certera aplicación del método científico —observación, documentación, análisis, conclusiones meditadas y demostradas-, el resultado no podía ser sino excelente y altamente recomendable.

\section{BIBLIOGRAFÍA}

Aínsa, F. (1990) Necesidad de la utopía. Montevideo: Comunidad del Sur-Edinor.

Bazin, A (1990) ¿Qué es el cine? Madrid: Rialp.

Elena, A. (1999) Los cines periféricos: África, Oriente Medio, India. Barcelona: Paidós.

Marx, K. y Engels, F. (2011) Manifiesto comunista. Madrid: Alianza.

Neira Piñeiro, R. (2004-2005) "El lenguaje poético del cine: procedimientos de simbolización en Un día de campo". En Archivum, 56: 291-311.

Nietzsche, F. (2011) El Anticristo. Buenos Aires: Losada.

Ordóñez del Pino, V. (2011) "La docencia de la historia de África subsahariana a través del cine africano". Quaderns de cine, 7: 17-28.

Quevedo Revenga, V. (2011) "La voz de cine africano. Desde sus orígenes al presente". En Quaderns de cine, 7: 7-16.

Rodríguez Barranco, F. J. (2015) 2009, un año de Cine Nostrum. Málaga: Azimut.

Sadoul, G. (2004) Historia del cine mundial: desde los orígenes. México: Siglo XXI.

Shafik, V. (2008) "El cine árabe actual: tendencias y retos". Culturas, 2: 96-110.

Enrique GALLUD JARDIEL

Narrador, ensayista, profesor de Literatura Española egjardiel@gmail.com 